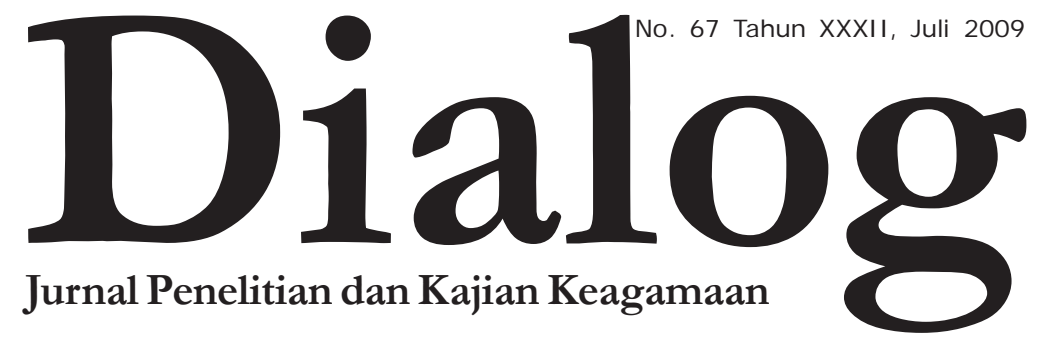

PERBANKAN SYARIAH DI INDONESIA

\begin{tabular}{|l|l|l|l|l|l|}
\hline Jurnal & $\begin{array}{l}\text { Nomor } \\
\text { Dialog }\end{array}$ & $\begin{array}{l}\text { Tahun } \\
\text { XXXII }\end{array}$ & $\begin{array}{l}\text { Halaman } \\
137\end{array}$ & Jakarta & ISSN \\
Juli 2009 & 0126-396X \\
\hline
\end{tabular}




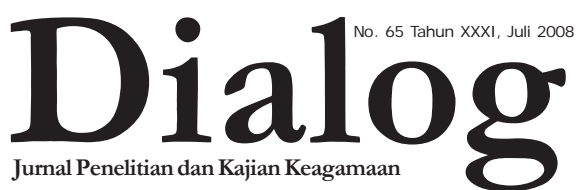

Pemi mpin Umum:

Prof. Dr. H. M. Atho Mudzhar, MA

Redaktur Aht :

Prof. Dr. H. Nasaruddin Umar, MA

Prof. Dr. H. Komarudin Hidayat, MA

Pemimpin Redaksi / Penanggung J awab

Drs. H. Syamsuddin

Waki l Pemi mpin Redaksi

H. Fanani Suprianto, SH., MM

Sekretaris Redaksi

M. Rosyid Fauzi, S.Si.

Dewan Redaksi

Prof. Dr. H. Abdurrahman Mas'ud

Drs. Amin Haedari

Prof. Dr. H. Maidir Harun

Drs. H. Mohammad Shohib, MA

Drs. H. Asmu'i, SH, MM

Chamdi Pamudji, SH., MM

Redaktur Eksekutif

M. Nasir, S.Th.I.

Redaktur Pelaksana

Moh. Rosyid Fauzi, S.Si

M. Nasir, S.Th.I

M. Adlin Sila, M.A

Abbas Jauhari, M.Ag

Admi ni strası

Drs. Dedy Curipno

Sutidjah

Desriyanti Nasution, S.IPI

Drs. H. Sahlani

Alamat Redaksi

Gedung Bayt Alquran Museum Istiqlal Komplek Taman Mini Indonesia Indah

Telp. (021) 87791444-87794982

Website:

www. balitbangdiklat.depag.go.id

Email:

info@depag.web.id

\section{PEIGITIR REDIKSL}

Karakteristik sistem perbankan syariah yang beroperasi berdasarkan prinsip bagi hasil memberikan alternatif sistem perbankan yang saling menguntungkan bagi masyarakat dan bank, serta menonjolkan aspek keadilan dalam bertransaksi, investasi yang beretika, mengedepankan nilai-nilai kebersamaan dan persaudaraan dalam berproduksi, dan menghindari kegiatan spekulatif dalam bertransaksi keuangan. Dengan menyediakan beragam produk serta layanan jasa perbankan yang beragam dengan skema keuangan yang lebih bervariatif, perbankan syariah menjadi alternatif sistem perbankan yang kredibel dan dapat dinikmati oleh seluruh

Jurnal Dialog diterbitkan oleh Badan Litbang dan Diklat Departemen Agama RI, sebagai media informasi dalam rangka mengembangkan penelitian dan kajiaan keagamaan di Indonesia. Dialog berisi tulisan ilmiah dan hasil penelitian dan pengembangan terkait dengan masalah keagamaan. Redaksi mengundang para peneliti agama, pengamat, cendekiawan, intelektual, dan akademisi untuk berdiskusi dan menulis secara bebas serta kreatif demi pengembangan penelitian maupun kajian keagamaan di Indonesia.

2 Dialog No. 67 Tahun XXXII, Juli 2009 
golongan masyarakat Indonesia tanpa terkecuali.

Fungsi Bank Syariah secara garis besar tidak berbeda dengan bank konvensional, yakni sebagai lembaga intermediasi (intermediary institution) yang mengerahkan dana dari masyarakat dan menyalurkan kembali dana-dana tersebut kepada masyarakat yang membutuhkannya dalam bentuk fasilitas pembiayaan. Perbedaan pokoknya terletak dalam jenis keuntungan yang diambil bank dari transaksi-transaksi yang dilakukannya. Bila bank konvensional mendasarkan keuntungannya dari pengambilan bunga, maka Bank Syariah dari apa yang disebut sebagai imbalan, baik berupa jasa (fee-base income) maupun mark-up atau profit margin, serta bagi hasil (loss and profit sharing).

Disamping dilibatkannya Hukum Islam dan pembebasan transaksi dari mekanisme bunga (interest free), posisi unik lainnya dari Bank Syariah dibandingkan dengan bank konvensional adalah diperbolehkannya Bank Syariah melakukan kegiatankegiatan usaha yang bersifat multifinance dan perdagangan (trading). Hal ini berkenaan dengan sifat dasar transaksi Bank Syariah yang merupakan investasi dan jual beli serta sangat beragamnya pelaksanaan pembiayaan yang dapat dilakukan Bank Syariah, seperti pembiayaan dengan prinsip murabahah (jual beli), ijarah (sewa) atau ijarah wa iqtina (sewa beli) (Farouk, 2009), dan lain-lain.
Dalam kajian Jurnal Dialog Edisi ini mencoba menyoroti perkembangan Perbankan Syariah di Indonesia yang beberapa tahun belakangan ini cukup mengalami perkembangan yang signifikan. Sehingga tidak sedikit bank konvensional yang membuka divisi syariah guna berebut nasabah yang kian meminati sistem perbankan syariah. Kajian Jurnal Dialog edisi ini diawali dengan tulisan Dr. Euis Amalia yang mengulas tentang Perbankan Syariah di Indonesia: Kontribusinya Bagi Perekonomian Nasional dan Peran Perguruan Tinggi dalam Rangka Akselerasi. Dilanjutkan dengan tulisan Muhammad Taufiki, M.Ag yang mengupas tentang Aplikasi Konsep Hilah dalam Pengembangan Produk Perbankan Syariah (Analisa terhadap Fatwa tentang Syariah Charge Card).

M. Adlin Sila, MA, peneliti di Badan Litbang dan Diklat Depag mencoba mengulas kemungkinan Bank Syariah Sebagai Bank Bagi Hasil? Ah. Azharuddin Lathif, M.Ag, MH, Dosen Fakultas Syariah dan Hukum UIN Jakarta menghadirkan tulisan tentang Analisis Yuridis Pengenaan Pajak Pertambahan Nilai (Ppn) Dalam Pembiayaan Murabahah di Perbankan Syariah. Sedangkan Prof. Dr. Abd. Rachman Mas'ud Kepala Puslitbang Kehidupan Keagamaan, melalui tulisannya mencoba menyoroti Etika Professional dan Ruh Agama di Awal Millenium. Yulizar D. Sanrego \& Aam S. Rusydiana dosen di Tazkia Institute 
menghadirkan tulisan tentang Peran Perbankan Syariah dalam Mendukung Umkm Pertanian. Kajian ini dilengkapi dengan tulisan Iyoh Masthiyah Peneliti Puslitbang Pendidikan Agama dan Keagamaan Badan Litbang dan Diklat Depag tentang Hak Milik dalam Islam Perspektif Ibn Taymiyah. Kajian dalam Jurnal Dialog edisi ini kian lengkap dengan hadirnya tulisan Yulianti Muhammad yang menganalisis Prospek Perbankan Syariah di Indonesia.

Di samping memuat artikel ilmiah, Jurnal Dialog edisi ini juga memuat laporan hasil penelitian oleh
Dr. Anwar Abbas tentang Ekonomi Islam dan Pemberdayaan Ekonomi Rakyat; Studi Kasus Pemberdayaan Melalui Koperasi Pondok Pesantren Sidogiri Kab. Pasuruan Jawa Timur. Kajian ini diakhiri dengan telaah buku yang mengulas buku karya Drs. Cik Basir, SH, MHI, 2009. Penyelesaian Sengketa Perbankan Syariah di Pengadilan Agama dan Mahkamah Syar'iyah. Semoga kajian yang dihadirkan Jurnal Dialog edisi ini memberikan manfaat yang berarti bagi para pembaca, khususnya dalam kajian Perbankan Syariah di Indonesia. Selamat Membaca!

Redaksi 


\section{DIPTIRISI}

\section{TOPIK}

PERBANKAN SYARIAH DI INDONESIA:

Kontribusinya Bagi Perekonomian Nasional dan

Peran Perguruan Tinggi dalam Rangka Akselerasi

Euis Amalia -6

APLIKASI KONSEP HILAH

DALAM PENGEMBANGAN PRODUK PERBANKAN SYARIAH

(Analisa terhadap Fatwa tentang Syariah Charge Card)

H. Muhammad Taufiki -20

BANK SYARIAH SEBAGAI BANK BAGI HASIL: MUNGKINKAH?

M. Adlin Sila -30

ANALISIS YURIDIS PENGENAAN

PAJAK PERTAMBAHAN NILAI (PPN)

DALAM PEMBIAYAAN

MURABAHAH DI PERBANKAN SYARIAH

Ah. Azharuddin Lathif -52

ETIKA PROFESSIONAL DAN RUH AGAMA

DI AWAL MILLENIUM

Abd. Rachman Mas'ud -69

PERAN PERBANKAN SYARIAH DALAM

MENDUKUNG UMKM PERTANIAN

Yulizar D. Sanrego \& Aam S. Rusydiana -74

HAK MILIK DALAM ISLAM PERSPEKTIF IBN TAYMIYAH

Iyoh Masthiyah --90

PROSPEK PERBANKAN SYARIAH

DI INDONESIA: CERAH ATAU BURAM?

Yulianti Muhammad --101

\section{PENELITIAN}

EKONOMI ISLAM DAN

PEMBERDAYAAN EKONOMI RAKYAT; Studi Kasus Pemberdayaan Melalui

Koperasi Pondok Pesantren Sidogiri Kab. Pasuruan Jawa Timur

Anwar Abbas -117

\section{BOOK REVIEW}

PENYELESAIAN SENGKETA PERBANKAN SYARIAH

(Di Pengadilan Agama dan Mahkamah Syariah)

R. Meilani Dewi - 132 


\title{
TOPIK ANALISIS Yuridis Pengenaan Pajak Pertambahan Nilai (PPN) Dalam Pembiayaan MURABaHaH di Perbankan Syariah
}

\author{
OLEH: AH. AZHARUDDIN LATH IF, M.Ag, M H *
}

\begin{abstract}
:
The requirement of the Value Added Tax (PPN/ Pajak Pertambahan Nilai) on the murabahah endowment at the Islamic banking has created legal problems and led to the Islamic banking insolvency or ruin. Such ruin will mainly results from the fact that the murabahah product at the Islamic banking is not compatible with the credit applied in the conventional banking that is freed from the PPN. This is ironic as the existence of the Islamic banking is badly needed within the Indonesian society to become an alternative to the financial conventional institution or system. On the other hand, it must be openly acknowledged that the entitlement of tax, including PPN, which constitutes the source of national income, is truly necessitate, as when the murabahah product is freed from PPN, the income from the tax sector would be decreased. This article attempts to study and review this puzzling problem through legal and juridical approach.
\end{abstract}

\section{A. Pendahuluan}

Sebagai lembaga intermediary keuangan, bank syari'ah memiliki kegiatan utama berupa penghimpunan dana dari masyarakat melalui simpanan dalam bentuk giro, tabungan, dan deposito yang menggunakan prinsip wadi'ah yand dlamanah (titipan), dan mudharabah (investasi bagi hasil). Kemudian menyalurkan kembali dana tersebut kepada masyarakat umum dalam berbagai bentuk skim pembiayaan, seperti skim jual beli/alba'i (murabahah, salam, dan istishna), sewa (ijarah), dan bagi hasil (musyarakah dan mudharabah), serta produk pelengkap, yakni fee based service, seperti hiwalah (alih utang piutang), rahn

*Dosen Fakultas Syariah dan Hukum UIN Jakarta

52 Dialog No. 67 Tahun XXXII, Juli 2009 (gadai), qard (utang piutang), wakalah (perwakilan, agency), kafalah (garansi bank). ${ }^{1}$

Kontrak pada perbankan syariah memiliki sejumlah perbedaan mendasar dibandingkan dengan kontrak pebankan konvensional. Produk bank syariah secara umum menerapkan prinsip bagi hasil, jual-beli dan sewa/jasa, karena dalam ekonomi Islam yang menjadi dasar operasional bank syariah, pengenaan bunga pada pemberian pinjaman uang tidak diperkenankan. Namun, perbedaan ini,

${ }^{1}$ Widjanarto, Hukum dan Ketentuan Perbankan di Indonesia, (Jakarta: Pustaka Utama Grafiti,2003), edisi IV, h.59-61, Tim Bank Syari'ah Mandiri, Apa dan Bagaimana Bank Syari'ah, (Jakarta: BSM Cab. Meruya, 2005), h. 14-15. 
terutama dalam prinsip jual beli murabahah, membawa konsekwensi kurang kompetitifnya produk bank syari'ah dibandingkan bank konvensional. Ini karena pemberian jasa keuangan berupa kredit dalam bank konvensional tidak dikenakan Pajak Penambahan Nilai (PPN), sementara pembiayaan dalam perbankan syari'ah khususnya yang menggunakan skim jual beli murabahah ${ }^{2}$ secara hukum dikenakan Pajak Pertambahan Nilai (PPN) sebanyak dua kali. Mengapa terjadi perlakuan hukum PPN yang berbeda antara kredit di bank konvensional dengan pembiayaan murabahah diperbankan syari'ah? Adakah upaya yang bisa dijadikan solusi untuk mengatasinya?

\section{B. Polemik Pengenaan PPN dalam Pembiayaan Murabahah}

Jasa perbankan sebagaimana ditetapkan dalam UU No. 8 Tahun 1983 yang telah diubah terakhir dengan UU No. 18 Tahun 2000 merupakan salah satu jasa yang tidak menjadi obyek Pajak Pertambahan Nilai (PPN). Namun, ketika ketentuan ini diterapkan pada pembiayaan murabahah yang menjadi produk unggulan perbankan syariah, terjadi perbedaan pandangan di antara pihak-pihak yang terkait. Terutama dalam hal ini adalah Direktorat Jenderal Pajak Departemen Keuangan RI dan industri perbankan syariah. Menurut Direktorat Jenderal Pajak, pembiayaan murabahah harus

\footnotetext{
${ }^{2}$ Murabahah adalah transaksi penjulan barang dengan menyatakan harga perolehan dan keuntungan (margin) yang disepakati oleh penjual dan pembeli. Tim Penyusun, Pedoman Akuntansi Perbankan Syariah Indonesia, (Jakarta: Ikatan Akuntan Indonesia, 2003), Cet. 1, hlm. 32
}

dikenakan Pajak Pertambahan Nilai karena prinsip akad atau transaksi yang melandasi pembiayaan ini adalah jual beli. ${ }^{3}$ Sedangkan menurut para praktisi perbankan termasuk pihak Bank Indonesia sebagai pemegang otoritas tertinggi perbankan di Indonesia. Menilai bahwa pembiayaan murabahah merupakan salah satu jasa perbankan syariah yang tidak dikenakan Pajak Pertambahan Nilai sebagaimana produk pembiayaan atau kredit di bank konvensional. Ini karena bank syariah sebagaimana bank konvensional hanya berfungsi sebagai lembaga intermediary keuangan. ${ }^{4}$

Polemik tentang pengenaan Pajak Pertambahan Nilai pada pembiayaan murabahah di perbankan syariah ini mengemuka sejak Direktur Jenderal Pajak mengeluarkan surat Edaran No. 243/PJ.53/2003, tanggal 10 Maret 2003 dan S-1071/PJ.53/2003, tanggal 4 September 2003 yang menyatakan bahwa kegiatan jual beli murabahah oleh perbankan syariah tidak termasuk jenis jasa di bidang perbankan yang dikecualikan dari $\mathrm{PPN}^{5}$, karena murabahah dilakukan berdasarkan

${ }^{3}$ Heru Marhanto Utomo, Kepala Seksi Peraturan PPN Jasa Direktorat Jenderal Pajak Departemen Keuangan RI, Wawancara Pribadi, Jakarta, 1 Agustus 2007

${ }^{4}$ Cecep Maskanul Hakim, Peneliti Bank Indonesia, Wawancara Pribadi, Jakarta, 12 Nopember 2007

${ }^{5}$ Menurut Direktorat Pajak pengenaan PPN pada produk murabahah sebenarnya sudah ada sejak produk tersebut diperkenalkan Bank Muamalat Indonesia tahun 1992. karena sejak diberlakukannya UU PPN (Undang-Undang Nomor 8 Tahun 1983), dimana pada dasarnya PPN dikenakan atas setiap/semua penyerahan Barang Kena Pajak dan/atau Jasa Kena Pajak, termasuk murabahah. Heru Marhanto Utomo, Wawancara Pribadi, Loc.Cit.

Dialog No. 67 Tahun XXXII, Juli 2009 53 
prinsip jual beli, sehingga penyerahan barang tersebut dari bank kepada nasabah menjadi penyerahan barang kena pajak yang terhitung Pajak Pertambahan Nilai. ${ }^{6}$

Ketentuan dalam surat Dirjen Pajak tersebut berbeda dengan surat yang pernah dikeluarkan Dirjen Pajak sebelumnya, pada tahun 1992, yang menyatakan bahwa pembiayaan murabahah merupakan salah satu pembiayaan perbankan syariah yang dibebaskan dari pengenaan PPN. Berkaitan dengan hal ini mantan direktur utama Bank Muamalat Indonesia (BMI) A. Riawan Amin menyatakan bahwa pada saat awal berdirinya Bank Muamalat Indonesia, Departemen Keuangan pernah menerbitkan surat bernomor S-103/PJ.3/ 1992, yang salah satu isinya pengecualian PPN atas murabahah. Dalam surat tertanggal 12 Mei 1992 itu, salah satu butirnya menyebutkan bahwa penyaluran Barang Kena Pajak (BKP) dari pemasok pada BMI dalam rangka penyaluran dana BMI yang berbentuk pembiayaan modal kerja dan pembiayaan investasi, tak dianggap sebagai penyerahan kena pajak, karena itu tak terutang PPN. ${ }^{7}$

Polemik tentang PPN pada pembiayaan murabahah ini bertambah panas ketika Direktorat Jenderal Pajak

${ }^{6}$ Surat Edaran Direktur Jenderal Pajak Kepada Direksi PT. Bank Muamalat Indonesia No. 243/ PJ.53/2003, tanggal 10 Maret 2003 dan S-1071/ PJ.53/2003, tanggal 4 September 2003, Sumber MISTAX BANK Muamalat Indonesia

${ }^{7}$ Riawan Amin, Bisnis-Indonesia, : "APPI adukan PPN leasing, 'Transaksi murabahah bukan obyek PPN", Jakarta, 20 Maret 2006, h. 13 dan juga lihat surat Direktur Jenderal Pajak Kepada Direksi PT. Bank Muamalat Indonesia nomor: S-103/PJ.3/ 1992 tanggal 12 Mei 1992.

54 Dialog No. 67 Tahun XXXII, Juli 2009 memeriksa tahun pajak 2003 Bank Syariah Mandiri (BSM) dan menerbitkan Surat Ketetapan Pajak Kurang Bayar (SKPKB) PPN No. 00032/ 207/03/073/04 tanggal 13 Desember 2004 sebesar Rp25,5 miliar atas PPN murabahah. Ditjen Pajak selanjutnya menerbitkan keputusan penolakan atas keberatan BSM pada 1 Desember 2005 tentang Keberatan Surat Ketetapan Pajak PPN. Sebagai reaksi atas kebijakan Direktorat Jenderal Pajak tersebut, Asosiasi Perbankan Syariah Indonesia dan juga Bank Indonesia pada tahun 2005 pernah mengajukan surat permohonan agar Direktorat Jenderal Pajak tidak mengenakan PPN atas pembiayaan Murabahah dan agar Direktorat Jenderal pajak menyampaikan Surat Edaran kepada Kantor Pelayanan Pajak untuk tidak mengenakan PPN atas semua transaksi murabahah. Surat ini kemudian dibalas dengan surat Direktur Jenderal Pajak No. S-65/PJ.53/2006 tanggal 7 Pebruari 2006 yang isinya menegaskan bahwa permohonan pembebasan PPN atas transaksi murabahah tidak dapat dipenuhi. ${ }^{8}$

\section{Argumentasi Pro dan Kontra Pengenaan PPN Pada Produk Murabahah}

Polemik antara pihak Direktorat Jenderal Pajak dan Industri Perbankan Syariah tersebut memang sangat complicated, mengingat masing-masing pihak mengajukan argumentasi yang sama-sama kuat yang didasarkan pada

${ }^{8}$ Surat Direktur Jenderal Pajak Kepada Asosiasi Bank Syariah Indonesia (Asbisindo) No. S-65/PJ.53/ 2006 tanggal 7 Pebruari 2006 tentang Perlakuan PPN atas Produk Pembiayaan oleh Perbankan Syariah 
peraturan perundang-undangan yang pada saat ini berlaku di Indonesia. Baik peraturan yang terkait langsung dengan Pajak Pertambahan Nilai maupun Peraturan tentang Perbankan. Berikut akan dipaparkan argumentasi masing-masing.

Bagi pihak Direktorat Jenderal Pajak, pengenaan PPN atas pembiayaan murabahah didasarkan pada beberapa peratuan perundang-undangan berikut ini:

1. Undang-undang Nomor 8 Tahun 1983 tentang Pajak Pertambahan Nilai Barang dan Jasa dan Pajak Penjualan atas Barang Mewah sebagaimana telah beberapa kali diubah terakhir dengan Undangundang Nomor 18 Tahun 2000', antara lain mengatur:

a. Pasal 1 angka 2 menyatakan bahwa Barang adalah barang berwujud, yang menurut sifat atau hukumnya dapat berupa barang bergerak atau barang tidak bergerak, dan barang tidak berwujud.

b. Pasal 1 angka 3 menyatakan bahwa Barang Kena Pajak adalah barang sebagaimana dimaksud dalam angka 2 yang dikenakan pajak berdasarkan Undang-undang ini.

\footnotetext{
${ }^{9}$ Ketentuan tentang pengecualian produk jasa perbankan dari PPN telah diatur sejak tahun 1988 yaitu dengan keluarnya Peraturan Pemerintah (PP) Nomor 28 Tahun kemudian dilanjutkan dalam periode UU berikutnya (UU Nomor 11 Tahun 1994 dan UU Nomor 18 Tahun 2000) berturut-turut ditetapkan dalam PP Nomor 50 Tahun 1994 sebagaimana telah beberapa kali diubah terakhir dengan PP Nomor 59 Tahun 1999, dan PP Nomor 144 Tahun 2000, yaitu jasa di bidang perbankan ditetapkan sebagai jenis jasa yang tidak dikenakan PPN. Heru Marhanto Utomo, Wawancara Pribadi, Loc. Cit.
}

c. Pasal 1 angka 5 menyatakan bahwa jasa adalah setiap kegiatan pelayanan berdasarkan suatu perikatan atau perbuatan hukum yang menyebabkan suatu barang atau fasilitas atau kemudahan atau hak tersedia untuk dipakai, termasuk jasa yang dilakukan untuk menghasilkan barang karena pesanan atau permintaan dengan bahan dan atas petunjuk dari pemesan.

d. Pasal 1 angka 6 menyatakan bahwa Jasa Kena Pajak adalah jasa sebagaimana dimaksud dalam angka 5 yang dikenakan pajak berdasarkan Undangundang ini.

e. Pasal 1 angka 12 menyatakan bahwa perdagangan adalah kegiatan usaha membeli dan menjual, termasuk kegiatan tukar menukar barang, tanpa mengubah bentuk atau sifatnya.

f. Pasal 1 angka 14 menyatakan bahwa Pengusaha adalah orang pribadi atau badan yang dalam kegiatan usaha atau pekerjaannya menghasilkan barang, mengimpor barang, mengekspor barang, melakukan usaha perdagangan, memanfaatkan barang tidak berwujud dari luar Daerah Pabean, melakukan usaha jasa, atau memanfaatkan jasa dari luar Daerah Pabean.

Pasal 1A ayat (1) huruf a menyatakan bahwa termasuk dalam pengertian penyerahan Barang Kena Pajak adalah penyerahan hak atas Barang 
Kena Pajak karena suatu perjanjian.

Penjelasan Pasal ini menyatakan bahwa perjanjian yang dimaksudkan dalam ketentuan ini meliputi jual beli, tukar menukar, jual beli dengan angsuran, atau perjanjian lain yang mengakibatkan penyerahan hak atas barang.

g. Pasal 4 huruf a menyatakan bahwa Pajak Pertambahan Nilai dikenakan atas penyerahan Barang Kena Pajak di dalam Daerah Pabean yang dilakukan oleh Pengusaha.

2. Peraturan Pemerintah Nomor 144 Tahun 2000 tentang Jenis Barang dan jasa Yang Tidak dikenakan Pajak Pertambahan Nilai Barang dan Jasa antara lain mengatur:

a. Pasal 4A ayat (2) jo. Pasal 1, menetapkan jenis-jenis barang yang tidak dikenakan Pajak Pertambahan Nilai yaitu: barang hasil pertambangan atau hasil pengeboran, yang diambil langsung dari sumbernya; barang-barang kebutuhan pokok yang sangat dibutuhkan oleh rakyat banyak; makanan dan minuman yang disajikan di hotel, restoran, rumah makan, warung, dan sejenisnya; dan uang, emas batangan, dan surat-surat berharga.

b. Pasal $4 \mathrm{~A}$ ayat (3) jo. Pasal 5 huruf d dan Pasal 8 huruf a Peraturan Pemerintah Nomor 144 Tahun 2000 tentang Jenis Barang dan Jasa yang Tidak Dikenakan Pajak Pertambahan Nilai, menetapkan jasa perbankan sesuai dengan ketentuan sebagaimana diatur dalam Undang-undang Nomor 7 Tahun 1992 tentang Perbankan beserta perubahannya (kecuali jasa penyediaan tempat untuk menyimpan barang dan surat berharga, jasa penitipan untuk kepentingan pihak lain berdasarkan suatu kontrak (perjanjian), dan jasa anjak piutang) sebagai jenis jasa yang tidak dikenakan Pajak Pertambahan Nilai.

c. Pasal 5 huruf d antara lain menyatakan bahwa jasa di bidang perbankan termasuk jenis jasa yang tidak dikenakan Pajak Pertambahan Nilai

d. Pasal 8 huruf a antara lain menyatakan bahwa Jasa perbankan sesuai dengan yang dimaksud pasal 5 huruf $d$ adalah jasa perbankan sesuai dengan ketentuan sebagaimana diatur dalam Undang-undang Nomor 7 Tahun 1992 tentang Perbankan sebagaimana telah diubah dengan Undangundang Nomor 10 Tahun 1998, kecuali jasa penyediaan tempat untuk menyimpan barang dan surat berharga, jasa penitipan untuk kepentingan pihak lain berdasarkan suatu kontrak (perjanjian), serta anjak piutang.

3. Undang-undang Nomor 7 Tahun 1992 tentang Perbankan sebagaimana telah diubah dengan Undang-undang Nomor 10 Tahun 1998, antara lain mengatur: 
a. Pasal 1 angka 13 menyatakan bahwa Prinsip Syariah adalah aturan perjanjian berdasarkan hukum Islam antara bank dan pihak lain untuk penyimpanan dana dan atau pembiayaan kegiatan usaha, atau kegiatan lainnya yang dinyatakan sesuai dengan Syariah, antara lain pembiayaan berdasarkan prinsip bagi hasil (mudharabah), pembiayaan berdasarkan prinsip penyertaan modal (musharakah), prinsip jual beli barang dengan memperoleh keuntungan (murabahah), atau pembiayaan barang modal berdasarkan prinsip sewa murni tanpa pilihan (ijarah), atau dengan adanya pilihan pemindahan kepemilikan atas barang yang disewa dari pihak bank oleh pihak lain (ijarah wa iqtina).

b. Pasal 6 huruf m menyatakan bahwa usaha bank umum antara lain adalah menyediakan pembiayaan dan atau melakukan kegiatan lain berdasarkan Prinsip Syariah, sesuai dengan ketentuan yang ditetapkan oleh Bank Indonesia.

4. Peraturan Bank Indonesia Nomor 5/7/PBI/2003 tentang Kualitas Aktiva Produktif bagi Bank Syariah, antara lain mengatur:

a. Pasal 1 angka 1 menyatakan bahwa Bank Syariah adalah bank umum sebagaimana dimaksud dalam Undangundang Nomor 7 Tahun 1992 tentang Perbankan sebagaimana telah diubah dengan Undang-undang
Nomor 10 Tahun 1998 yang melakukan kegiatan usaha berdasarkan prinsip Syariah, termasuk unit usaha Syariah dan kantor cabang bank asing yang melakukan kegiatan usaha berdasarkan prinsip Syariah.

b. Pasal 1 angka 9 menyatakan bahwa murabahah adalah perjanjian jual beli antara bank dan nasabah, dimana bank Syariah membeli barang yang diperlukan oleh nasabah dan kemudian menjualnya kepada nasabah yang bersangkutan sebesar harga perolehan ditambah dengan margin/ keuntungan yang disepakati antara bank Syariah dan nasabah.

5. Pernyataan Standar Akuntansi Keuangan Nomor 59 tanggal 1 Mei 2002 tentang Akuntansi Perbankan Syariah, antara lain menetapkan bahwa dalam transaksi murabahah:

a. harga yang disepakati dalam murabahah adalah harga jual, sedangkan harga beli harus diberitahukan (Paragraf 57);

b. bank dapat meminta nasabah menyediakan agunan atas piutang murabahah, antara lain, dalam bentuk barang yang telah dibeli dari bank (Paragraf 58); dan

c. pada saat perolehan, aktiva yang diperoleh dengan tujuan untuk dijual kembali dalam murabahah diakui sebagai aktiva murabahah sebesar biaya perolehan (Paragraf 61).

6. Fatwa Dewan Syariah Nasional (DSN) NO: 04/DSN-MUI/IV/2000 yang menjelaskan bahwa dalam jual 
transaksi murabahah bank membeli barang yang diperlukan nasabah atas nama bank sendiri, dan pembelian ini harus sah dan bebas riba.

7. Berdasarkan ketentuan pada butir 2 sampai dengan butir 6, dengan ini ditegaskan bahwa m e s ki pu n transaksi murabahah merupakan salah satu kegiatan usaha yang dapat dilakukan oleh bank Syariah, namun mengingat prinsip yang mendasari transaksi tersebut adalah jual beli, maka dari sisi UndangUndang Pajak Pertambahan Nilai yang saat ini berlaku transaksi tersebut tidak dapat dikategorikan sebagai jasa perbankan, melainkan merupakan kegiatan perdagangan.Oleh karena itu, penyerahan Barang Kena Pajak dalam rangka transaksi murabahah, baik oleh pemasok/ produsen kepada bank maupun oleh bank kepada nasabah, sepanjang pihak yang melakukan penyerahan adalah Pengusaha Kena Pajak (PKP), merupakan penyerahan Barang Kena Pajak yang terutang Pajak Pertambahan Nilai. Akan tetapi, Apabila barang yang diserahkan/ diperjualbelikan dalam transaksi murabahah adalah bukan Barang Kena Pajak, maka atas penyerahan barang tersebut tidak dikenakan Pajak Pertambahan Nilai. ${ }^{10}$

Sedangkan, Dalam hal transaksi-transaksi di atas bank meminta nasabah untuk menyediakan Barang Kena Pajak

${ }^{10}$ Diolah dari Surat Direktur Jenderal Pajak No. 243/PJ.53/2003 dan S-1071/PJ.53/2003 serta S-65/ PJ.53/2006 serta Heru Marhanto Utomo, Wawancara Pribadi, Loc. Cit

58 Dialog No. 67 Tahun XXXII, Juli 2009

Wazancara Pribadi, Loc. Cit tertentu sebagai jaminan/agunan, maka penyerahan Barang Kena Pajak dimaksud oleh nasabah kepada pihak bank bukan merupakan penyerahan Barang Kena Pajak yang terutang Pajak Pertambahan Nilai.

Sementara itu, argumentasi yang dikemukakan oleh kalangan praktisi perbankan syariah adalah sebagai berikut:

1. Merujuk pada argumentasi Direktorat Jenderal Pajak tentang definisi jasa perbankan adalah didasarkan pada UU Perbankan Nomor 7 Tahun 1992 tentang Perbankan sebagaimana telah diubah dengan Undang-undang Nomor 10 Tahun 1998, di dalam UU perbankan tersebut istilah "jasa perbankan" tidak disebutkan secara eksplisit. Yang ada hanya istilah bank umum, sebagaimana tertuang dalam pasal 1 angka 3 UU Perbankan, yaitu bank yang melaksanakan kegiatan usaha secara konvensional dan/atau secara prinsip syariah yang dalam kegiatannya memberikan jasa dalam lalu lintas pembayaran. Berdasarkan definisi bank umum di atas, jelas bahwa seluruh kegiatan bank umum, baik konvensional maupun syariah adalah memberikan jasa dalam lalu lintas pembayaran seperti dijelaskan dalam UU perbankan di atas. Salah satu jasanya adalah jasa pembiayaan berdasarkan prinsip jual beli barang dengan memperoleh keuntungan (murabahah). Dengan demikian, atas kegiatan murabahah tidak terhutang PPN karena termasuk 
dalam kategori jasa perbankan yang dikecualikan dari PPN. ${ }^{11}$

2. Pada pasal 6 UU Perbankan Nomor 7 Tahun 1992 tentang Perbankan sebagaimana telah diubah dengan Undang-undang Nomor 10 Tahun 1998, antara lain menjelaskan bahwa termasuk usaha bank umum adalah menyediakan pembiayaan dan atau melakukan kegiatan lain berdasarkan prinsip syariah sesuai dengan ketentuan yang ditetapkan Bank Indonesia. Dengan demikian yang punya otoritas untuk menentukan dan menetapkan apakah pembiayaan murabahah adalah usaha atau jasa perbankan adalah Bank Indonesia. Berdasarkan PBI No.6/17/2004, menetapkan bahwa murabahah adalah salah satu jenis usaha bank syariah. Lebih jauh lagi, dalam pasal 3 PBI Nomor 9/19/PBI/2007 tentang pelaksanaan prinsip syariah dalam kegiatan penghimpunan dan penyaluran dana serta pelayanan jasa Bank syariah, ditegaskan bahwa ...dalam kegiatan penyaluran dana berupa pembiayaan dengan mempergunakan antara lain Akad Mudharabah, Musyarakah, Murabahah, Salam, Istishna', Ijarah, Ijarah Muntahiyyah bit Tam lik dan Qardh..." Atas dasar kedua PBI tersebut jelas bahwa Pembiayaan murabahah sebagaimana halnya pembiayaan dengan mempergunakan antara lain Akad Mudharabah, Musyarakah, Salam, Istishna', Ijarah, Ijarah Muntahiyyah bit Tam lik, secara

\footnotetext{
${ }^{11}$ Tim Bank Indonesia, Perpajakan dalam Perbankan Syariah, (Jakarta: Bank Indonesia, 2005), h. 76
}

kategoris masuk dalam kategori jasa perbankan yang oleh UU No. 18/ 2000 Pasal 4A ayat (3) jo. Pasal 5 huruf d dan Pasal 8 huruf a Peraturan Pemerintah Nomor 144 Tahun 2000 tentang Jenis Barang dan Jasa yang Tidak Dikenakan Pajak Pertambahan Nilai.

3. Surat Direktur Jenderal Pajak Nomor S-103/PJ.3/1992 tanggal 12 Mei 1992 antara lain menegaskan bahwa perlakuan perpajakan atas pembiayaan yang dilakukan bank berdasarkan syariah dipersamakan dengan pembiayaan bank umum dimana tidak dikenakan PPN.

Atas dasar argumentasi tesebut di atas, maka Surat Direktur Jenderal Pajak No. 243/PJ.53/2003 dan S-1071/PJ.53/2003 yang menyatakan bahwa kegiatan jual beli murabahah oleh perbankan syariah tidak termasuk jenis jasa di bidang perbankan yang dikecualikan dari PPN, dinilai sangat lemah karena bertentangan dengan peraturan perundangundangan yang lebih tinggi, yaitu UU Perbankan Nomor 7 Tahun 1992 tentang Perbankan sebagaimana telah diubah dengan Undang-undang Nomor 10 Tahun 1998 jo. Peraturan Pemerintah Nomor 144 Tahun 2000 tentang Jenis Barang dan Jasa yang Tidak Dikenakan Pajak Pertambahan Nilai. Selain itu, juga kontradiktif dengan surat Direktur Jenderal sebelumnya Nomor S-103/PJ.3/1992 tanggal 12 Mei 1992 antara lain menegaskan bahwa perlakuan perpajakan atas pembiayaan yang dilakukan bank berdasarkan syariah dipersamakan dengan 
pembiayaan bank umum dimana tidak dikenakan PPN.

Selain mengajukan argumentasi yang bersifat yuridis, pihak praktisi perbankan juga mengemukakan beberapa alasan tambahan antara lain:

1. Pengenaan PPN atas pembiayaan murabahah merupakan kebijakan yang tidak adil, karena pada hakekatnya baik bank syariah maupun bank konvensional samasama menjalankan fungsi intermediary dalam bidang keuangan. Hanya saja, transaksi pembiayaan dalam perbankan syariah ada yang menggunakan akad murabahah yang dilaksanakan dengan prinsip jual beli barang. Ketidakadilan kebijakan ini akan berimplikasi tidak kompetitifnya bank syariah dibandingkan bank konvensional, juga lambat laun akan mampu mematikan industri perbanan syariah di Indonesia, padahal kontribusi Perbankan syariah sangat besar sebagai lembaga intermediary keuangan alternatif dari sistem perbanan konvensional. ${ }^{12}$ Dari sudut pandang makro ekonomi, pengenaan PPN pada produk murabahah akan memicu terjadinya inflansi. Hal ini menurut Dani Budianto bisa terjadi karena inputing tax yang tinggi tentu menyebabkan pricing bank menjadi tinggi juga, ini pada gilirannya berpengaruh pada kemampuan nasabah untuk mengangsur pembiayaan. Kalau nasabah tidak mempunyai kemampuan atau kolap nasabah tidak punya positioning

${ }^{12}$ Danni Budianto, Senior Trainer Muamalat Institut, Wawancara Pribadi, Jakarta, 16 Oktober 2007. power terhadap good akibatnya terjadi inflansi karena semua kredit bank akan macet. ${ }^{13}$

2. Negara-negara yang menerapkan prinsip bank syariah, seperti Malaysia, Inggris, Amerika, dan Singapura tidak mengenakan pajak pertambahan nilai pada produk pembiayaan murabahah. Malaysia telah mengamandemen Real Property Gains Tax (RPTG) Act 1976 pada tahun 1984. Di dalamnya ada pengaturan baru pada schedule 2 paragraf $3(\mathrm{~g})$, yang menyebutkan bahwa gains yang diperoleh oleh bank dengan penjualan aset kepada nasabah atas prinsip syariah dikecualikan dari pajak. Sementara Inggris, pada tahun 2003, melalui Financial Service Authority (FSA), badan independen yang menentukan regulasi keuangan di Inggris, telah menghapuskan pajak ganda yang menurut badan tersebut dianggap sebagai the main hurdle in the UK, dengan diintroduksinya Finace Act 2003. Amerika juga tidak mau ketinggalan dengan peluang bisnis perbankan syariah. Melalui Office of the Comptroller of the Currency (OCC), otoritas yang bertanggung jawab mengatur urusan moneter di negara itu, akhirnya mengeluarkan dua Interpretative Letters, yakni No 806 dan 867 terhadap National Bank Act of 1864 yang melarang industri perbankan melakukan transaksi jual beli. Kedua Interpretative Letters tersebut berisi tentang transaksi murabahah dan ijarah, dengan catatan tertentu dapat dikecualikan dari ketentuan yang disebutkan pada National Bank Act

\footnotetext{
${ }^{13}$ Danni Budianto, Wawancara Pribadi, Loc.Cit
} 
1864 tersebut. Sedangkan Singapura yang ingin menjadi raksasa perbankan Islam Asia melalui Monetary Authority of Singapore, sebagai yang diumumkan bersamaan dengan annual budged negara itu tahun 2005, telah menghapuskan pajak ganda pada Maret 2005. ${ }^{14}$

\section{Analisis Yuridis terhadap}

\section{Problem Pengenaan PPN Pada}

Produk Murabahah

Dari paparan polemik tentang pengenaan Pajak Pertambahan Nilai pada Produk pembiayaan murabahah di perbankan syariah di atas, jelas bahwa akar persoalannya terletak pada aspek yuridis. Beberapa persoalan yuridis yang timbul dari permasalahan di atas adalah:

1. Undang-Undang Nomor 8 Tahun 1983 tentang Pajak Pertambahan Nilai Barang dan Jasa dan Pajak Penjualan atas Barang Mewah sebagaimana telah beberapa kali dirubah terakhir dengan Undangundang Nomor 18 Tahun 2000 bersifat general dan sama sekali tidak menyinggung perlakuan PPN pada perbankan syariah. Demikian juga Peraturan Pemerintah Nomor 144 Tahun 2000 tentang Jenis Barang dan jasa Yang Tidak dikenakan Pajak Pertambahan Nilai Barang dan Jasa yang seharusnya menjelaskan lebih rinci tentang jasa pebankan yang dikecualikan dari PPN tenyata juga tidak menjelaskan

14 Cecep Maskanul Hakim, Wawancara Pribadi, Loc. Cit., Agus Triyanta, "Solusi Pajak Ganda Bank Syariah", Republika, 4 Pebruari 2007, hlm. 4. Klikpajak.com: "Peraturan Pajak baru hambat Pertumbuhan bank Syari'ah", 21 Pebruari 2006. secara tegas tentang pengecualian PPN pada produk perbankan syariah. Bahkan Keputusan Menteri Keuangan, atau Keputusan/Surat Edaran Direktorat Jenderal Pajak yang menjadi petunjuk tehnis atau petunjuk pelaksanaan (juknis/ juklak) tidak ada yang menjelaskan perincian tentang PPN di perbankan syariah. Yang ada hanyalah berupa surat Dirjen Pajak sebagai jawaban atas surat yang dikirimkan oleh Perbankan Syariah dan Asosiasi Perbankan Syariah. Oleh karena itu, dari sudut pandang hirarki peraturan perundang-undangan dasar hukum berupa surat Dirjen tersebut sangat lemah, apalagi surat dirjen bukan merupakan jenis peraturan perundang-undangan menurut Undang-undang No. 10 tahun 2004 tentang pembentukan Peraturan Perundang-Undangan, jadi tidak memiliki daya ikat dan daya paksa. Kondisi peraturan perundangundangan yang seperti ini sebenarnya yang menjadi pemicu adanya ketidakpastian hukum terhadap pengenaan PPN di perbankan syariah. Mungkin ketidaktegasan ini, disebabkan pada saat perumusan peraturan perundang-undangan tersebut pertumbuhan dan perkembangan perbankan syariah belum se pesat saat ini. Atau juga karena faktor ketergesa-gesaan dalam pembuatan perundang-undangan terutama yang lahir pasca reformasi 1998. Ini dapat dimengerti karena era reformasi membutukan langkah cepat guna menata kehidupan masyarakat termasuk diantaranya 
reformasi dibidang perpajakan. Terlepas dari segala kemungkinan alasan di atas, peraturan perundang-undangan tentang PPN tersebut di atas perlu segera disempurnakan dengan memperhatikan aspirasi dari kalangan praktisi perbankan agar tercapai keharmonisan hukum.

2. Penafsiran terhadap peraturan perundang-undangan yang masih general (umum) tersebut pada point-1 ternyata pada gilirannya memicu munculnya beberapa persoalan, di antaranya adalah persoalan lembaga mana yang memiliki otoritas untuk menafsirkan keumuman dari peraturan perundang-undangan tersebut? . Sebenarnya berdasarkan ketetuan perundang-undangan, lembaga yang berhak memberikan tafsiran atau perincian adalah lembaga yang ditunjuk oleh undang-undang terkait. Dalam konteks ini, yang berhak menafsirkan atau memerinci bagi pelaksanaan perundang-undangan perpajakan adalah Menteri Keuangan, termasuk di dalamnya Direktorat Jenderal Pajak sebagai bagian dari Kementrian Keuangan. Hal ini seperti yang ditegaskan dalam pasal 17 Peraturan Pemerintah Nomor 144 Tahun 2000, "Ketentuan lebih lanjut yang diperlukan bagi pelaksanaan Peraturan Pemerintah ini diatur dengan Keputusan Menteri Keuangan".

Namun demikian, ketika otoritas penafsiran atau perincian ini berkaitan dengan materi hukum tertentu, yaitu perincian tentang "yang termasuk jasa perbankan", yang terkait dengan Bank Indonesia, maka apakah hal ini masih menjadi wewenang Menteri Keuangan atau menjadi wewenang Bank Indonesia untuk menafsirkan atau memerinci yang masuk kategori jasa perbankan? Di sinilah letak persoalan pengenaan PPN pada produk murabahah di Perbankan Syariah. Berdasarkan penafsiran Direktorat Jenderal Pajak Departemen Keuangan sebagaimana yang diuraikan di atas, produk murabahah tidak dapat dikategorikan sebagai jasa perbankan, melainkan merupakan kegiatan perdagangan.Oleh karena itu, penyerahan Barang Kena Pajak dalam rangka transaksi murabahah, baik oleh pemasok/produsen kepada bank maupun oleh bank kepada nasabah, sepanjang pihak yang melakukan penyerahan adalah Pengusaha Kena Pajak, merupakan penyerahan Barang Kena Pajak yang terutang Pajak Pertambahan Nilai. Sedangkan menurut Bank Indonesia, produk murabahah termasuk dalam kategori jasa perbankan yang dikecualikan dari $P P N$. Dalam kaitan ini, sebenarnya otoritas penafsiran definisi yang termasuk jasa perbankan ada pada pihak Bank indonesia. Hal ini didasarkan pada Pasal 4A ayat (3) jo. Pasal 5 huruf d dan Pasal 8 huruf a Peraturan Pemerintah Nomor 144 Tahun 2000 tentang Jenis Barang dan Jasa yang Tidak Dikenakan Pajak Pertambahan Nilai, di mana peraturan tersebut menyerahkan penetapan jenis jasa perbankan yang dikecualikan dari PPN kepada Undang-undang Nomor 7 Tahun 1992 tentang Perbankan beserta 
perubahannya. Bukan kepada Peraturan Dirjen pajak. Sedangkan dari sudut pandang hirarki peraturan perundang-undangan, penafsiran atau perincian tentang "yang termasuk jasa perbankan" oleh Bank Indonesia dituangkan melalui PBI (Peraturan Bank Indonesia), sementara Penafsiran oleh Direktorat jenderal pajak hanya dituangkan melalui Surat Direktur Jenderal Pajak. Oleh karena itu, PBI tentu saja secara hirarki lebih tinggi kedudukannya dibandingkan dengan surat Dirjen Pajak. Hal ini sesuai dengan asas hukum lex Superiori derogat legi inferori, peraturan/ketentuan yang bersifat lebih tinggi derajatnya mengapus peraturan/ketentuan yang lebih rendah derajatnya. ${ }^{15}$

3. Selanjutnya pertentangan juga terjadi pada ketetapan pengenaan PPN pada produk murabahah yang didasarkan pada surat Direktur Jenderal Pajak. Pada surat Nomor S-103/PJ.3/1992 tanggal 12 Mei 1992 antara lain menegaskan bahwa perlakuan perpajakan atas pembiayaan yang dilakukan bank berdasarkan syariah dipersamakan dengan pembiayaan bank umum dimana tidak dikenakan PPN. Sementara dalam Surat Direktur Jenderal Pajak No. 243/PJ.53/2003 dan S-1071/PJ.53/2003 serta S-65/PJ.53/2006 menyatakan bahwa kegiatan jual beli murabahah oleh perbankan syariah tidak termasuk jenis jasa di bidang perbankan yang

${ }^{15}$ Jazim Jamidi dan Budiman N.P.D Sinaga, Pembentukan Peraturan Perundan-Undangan dalam Sorotan, (Jakarta: PT. Tatanusa, 2005), hlm. 46 . Bryan A Garnier (ed), Black's Law dictionary, (Amerika: Thomson, 2005) Cet- 8, hlm. 931 dikecualikan dari PPN. Pertentangan ini seharusnya tidak terjadi kalau surat Dirjen Pajak yang terakhir merujuk surat pertama dan menjelaskan adanya pembatalan surat pertama. Akan tetapi karena surat yang kedua dan ketiga, bahkan keempat tidak menyinggung sama sekali surat yang pertama maka timbul persoalan, surat Dirjen Pajak yang mana yang dapat dijadikan pedoman atau landasan hukum. Kalau dilihat dari prinsip atau asas hukum lex aposteriori derogat legi apiori $^{16}$, maka ketentuan yang paling akhir menghapus ketentuan terdahulu. Dalam kaitan ini, surat dirjen pajak S-65/PJ.53/2006 yang menyatakan bahwa kegiatan jual beli murabahah oleh perbankan syariah tidak termasuk jenis jasa di bidang perbankan yang dikecualikan dari PPN yang berlaku. Hanya saja, kalau kembali kepada argumentasi yuridis no. 2 di atas, maka jelas wewenang untuk menafsirkan produk perbankan yang dikecualikan dari PPN ada pada Bank Indonesia.

4. Sikap tegas Direktur Jenderal Pajak mengeluarkan surat sebagaimana disebutkan di atas, ternyata tidak diikuti dengan penegakan hukum yang berkelanjutan. Bahkan setelah Direktorat jenderal pajak memberikan surat penolakan keberatan pada Bank Mandiri untuk diterbitkan Surat ketetapan Pajak Kurang Bayar (SKPKB) Pajak PPN pada tahun 2005, ternyata Direktorat Jenderal Pajak tidak menindak lanjuti dengan tindakan

\footnotetext{
${ }^{16}$ Ibid.
} 
hukum selanjutnya yang menjadi wewenangnya, yaitu penagihan paksa atau bahkan pada tingkat penyitaan. Kondisi ini tentu saja akan menurunkan kredibilitas Direktorat Jenderal Pajak sebagai pemegang otoritas penegakan hukum di bidang pajak. Namun demikian, menurut beberapa responden sikap tersebut sengaja diambil karena pertimbangan politis. Hal ini mengingat desakan dari berbagai kalangan agar pemerintah RI mendukung pertumbuhan perbankan syariah. ${ }^{17}$ Jika hingga batas waktu tertentu tidak dilanjutkan penagihan PPN oleh fiskus, maka hutang pajak tersebut dianggap lunas dan tidak dapat ditagih lagi, atau dalam istilah hukum telah terjadi daluwarsa (lewat waktu). Menurut pasal 13 dan pasal 22 UU Nomor 28 tahun 2007 tentang Perubahan Ketiga Atas Undang-Undang Nomor 6 Tahun 1983 Tentang Ketentuan Umum Dan Tata Cara Perpajakan, hutang pajak akan daluwarsa jika setelah melampaui waktu 5 (lima) tahun terhitung sejak penerbitan Surat Tagihan Pajak, Surat Ketetapan Pajak Kurang Bayar, serta Surat Ketetapan Pajak Kurang Bayar Tambahan, dan Surat Keputusan Pembetulan, Surat Keputusan Keberatan, Putusan Banding, serta Putusan Peninjauan Kembali.

5. Meskipun masih terjadi polemik tentang kepastian hukum

${ }^{17}$ Cecep Maskanul Hakim, Peneliti Bank Indonesia, $\mathrm{O} p$. Cit, dan Hasanuddin, Sekretaris Dewan Syariah Nasional, Wawancara Pribadi, Jakarta, 17 Januari 2007 pengenaan PPN pada produk murabahah, ternyata mengundang beberapa bank syariah untuk melakukan perlawanan terhadap pajak dengan cara melakukan tindakan penghindaran pajak, yaitu dengan mengubah model transaksi murabahah yang berbasiskan jual beli barang secara langsung oleh bank kepada nasabah menjadi jual beli murabahah dengan sistem perwakilan (wakalah) atau dengan cara penyerahan barang hanya dilakukan sekali dari supplair langsung ke nasabah. Tindakan seperti ini memang masuk kategori pengindaran atau pengelakan pajak tetapi yang bersifat yuridis atau pengehindaran pajak secara legal, yaitu penghindaran pajak dalam bentuk perbuatan dengan cara sedemikian rupa sehingga perbuatan yang dilakukan tidak kena penerapan perundanundangan pajak. ${ }^{18}$ Biasanya perbuatan seperti ini terjadi karena terjadinya kekosongan hukum atau ketidakjelasan dari perundangundangan yang terkait. Walaupun secara hukum masih dalam kategori pengelakan pajak secara legal tetapi dari sudut pandang moralitas hukum Islam tetap saja mengandung persoalan tersediri dan merupakan tindakan yang tidak jujur dan trasparan serta menyalahi tujuan akad (maudhu alaqd) dalam kajian hukum Islam.

${ }^{18}$ Beberapa pakar pajak yang mengemukakan pendapat seperti ini di antaranya R. Santoso Brotodihardjo, Pengantar Ilmu Hukum Pajak, (Jakarta-Bandung: PT. Eresco, 1982 Ahmad Tjahjono dan Triyono Wahyudi, Perpajakan Indonesia; Pendekatan Soal jawab dan Kasus, (Jakarta: RajaGrafindo Persada, 2003), hlm. 25

64 Dialog No. 67 Tahun XXXII, Juli 2009 
padahal, kejujuran dan transparansi merupakan prinsip yang harus ditegakkan dalam perbankan syariah.

6. Istilah pajak ganda yang muncul dalam polemik pengenaan PPN pada produk murabahah di Perbankan Syariah ini sebenarnya tidak tepat digunakan. ${ }^{19}$ Istilah itu hanya tepat digunakan pada era UU PPN 1951, yang dalam pelaksana-annya, Pengusaha tidak diberi hak untuk memperoleh kembali PPN yang dibayar atas perolehan bahan baku/pembantu atau barang modal. Akibatnya, Pajak Penjualan yang terutang sepenuhnya merupakan hasil perkalian tarif PPN dengan peredaran bruto. Sedangkan berdasarkan UU PPN yang baru Kemungkinan pengenaan pajak berganda seperti yang dialami dalam era UU Pajak Penjualan (PPn) 1951 dapat dihindari sebanyak mungkin karena Pajak Pertambahan Nilai dipungut atas nilai tambah saja. Untuk memberikan gambaran yang lebih jelas tentang tidak terjadinya pajak ganda (double tax) dalam pemungutan PPN pada pembiayaan murabahah berikut ilustrasinya: Ahmad bermaksud mengajukan pembiayaan murabahah ke bank syariah $\mathrm{X}$ untuk pembelian mesin fotokopi sebagai modal kerja. Atas pembiayaan tersebut, Bank Syariah $x$ memesan mesin fotokopi ke supplier dengan harga jual Rp. 20 juta. Ketika supplier menyerahkan mesin foto kopi ke Bank maka dikenakan PPN 10\% (Rp. 20 juta $x$ $10 \%=$ Rp. 2 juta) sehingga harga perolehan sebesar Rp. 22 juta. Rp. 2 juta Ini merupakan Pajak Masukan (PM) bagi bank yang telah dibayarkan melalui supplier.. Kemudian Bank menjual mesin Fotokopi tersebut kepada Ahmad dengan mengabil margin keuntungan (ribh) sebesar 3 juta, sehingga harga jual sebesar (Rp. 22 juta + Rp 3 juta $=\operatorname{Rp} 25$ juta), setelah dikenakan PPN 10 \% (Rp. 25 juta x $10 \%=$ Rp. 2,5 Juta) maka harga perolehan yang harus di bayar oleh Ahmad sebesar Rp.27,5 juta. PPN Rp. 2,5 Juta tersebut merupakan Pajak Keluaran (PK) bagi Bank Syariah.Sehingga PPN yang disetor oleh bank syariah sebesar (Rp. 2,5 juta $(P K)-$ Rp. 2 juta $(P M)=R p$. 500 ribu).jadi yang disetor hanya selisih antara pajak keluaran dan pajak masukan, bukan double tax yang merupakan penjumlahan antara pajak masukan dan pajak keluaran sebesar (Rp. 2 juta + Rp. 2,5 juta = Rp. 4,5 juta).

Meskipun tidak terjadi istilah pajak ganda pada PPN produk murabahah, tetapi jika dibandingkan dengan harga yang ditawarkan oleh jasa lembaga keuangan bukan bank seperti jasa pembiayaan (leasing dengan hak opsi), harga yang ditawarkan Bank Syariah melalui Produk Murabahah ber-PPN tetap lebih tinggi, seperti yang diilustrasikan secara kuantitatif dalam tabel perhitungan berikut ini: 


\begin{tabular}{|l|r|r|r|r|r|}
\hline \multirow{2}{*}{ Deskripsi } & \multirow{2}{*}{ Pemasok } & \multicolumn{2}{c|}{ Prinsip Murabahah } & \multicolumn{2}{c|}{ Capital lesse } \\
\cline { 3 - 6 } & & $\begin{array}{c}\text { Bank } \\
\text { Syari'ah }\end{array}$ & Nasabah & Lessor & lessee \\
\hline Harga perolehan & 1.000 & 1.200 & 1.500 & 1.200 & 1.500 \\
\hline Nilai Tambah & 200 & 300 & - & 300 & - \\
\hline Pajak Masukan (PM) & 100 & 120 & 150 & 120 & 120 \\
\hline Pajak Keluaran (PK) & 120 & 150 & - & - & - \\
\hline $\begin{array}{l}\text { PPn Kurang Bayar (lebih } \\
\text { bayar) }\end{array}$ & 20 & 30 & $(150)$ & - & $(120)$ \\
\hline Reimbursement & - & - & - & $(120)$ & 120 \\
\hline Setor ke Kas Negara & 20 & 30 & - & - & - \\
\hline Restitusi yang & 1.000 & 1.200 & 1.650 & 1.200 & 1.620 \\
\hline $\begin{array}{l}\text { Kas bersih yang } \\
\text { dikeluarkan }\end{array}$ & - & - & 150 & - & 120 \\
\hline
\end{tabular}

Berdasarkan tabel perhitungan di atas, terlihat bahwa nasabah harus mengeluarkan kas yang lebih banyak jika membeli barang melalui mekanisme murabahah dibandingkan dengan pembiayaan leasing dengan hak opsi.

\section{E. Alternatif Solusi Penyelesaian PPN di Perbankan Syariah}

Dari paparan diatas jelas bahwa pengenaan Pajak Pertambahan Nilai (PPN) pada Pembiayaan Murabahah di Perbankan Syariah telah memicu timbulnya persoalan hukum atau yuridis dan berpotensi akan merugikan bank syariah yang pada gilirannya akan menyebabkan bangkrut dan hilangnya Perbankan Syariah di Indonesia. Padahal keberadaannya sangat dibutuhkan oleh masyarakat Indonesia sebagai alternatif dari sistem perbankan konvensional. Di sisi lain memang diakui bahwa keberadaan pajak sebagai sumber pendapatan negara (budgetter) sangat diperlukan sehingga dengan dibebaskannya produk murabahah dari PPN akan menyebabkan berkurangnya pendapatan sektor pajak.
Namun demikian, mengingat nilai stategis dari perbankan syariah di atas maka perlakuan pembebasan PPN pada perbankan konvensional perlu juga diberikan kepada perbankan syariah. Sedangkan beberapa kendala atau problem yuridis yang masih menjadi perdebatan di atas dapat ditawarkan solusi penyelesaian sebagai berikut:

Pertama, problem yuridis yang disebabkan oleh ketidaktegasan peraturan perundang-undangan yang mengatur PPN di perbankan syariah perlu segera diselesaikan dengan mempersiapkan rancangan amandemen undang-undang Pajak Pertambahan Nilai (PPN) yang mengakomodir kepentingan pengembangan perbankan syariah, yaitu dengan mengecualikan produk pembiayaan diperbankan syariah dari PPN. Meskipun pada saat ini sudah dipersiapkan tetapi dukungan sepenuh hati oleh semua pihak - pihak pemerintah dalam hal ini Departemen Keuangan (Direktorat Perpajakan), para anggota legislatif/DPR, Dewan Syariah Nasional MUI, dan pihak perbankan terutama Bank Indonesia serta 
masyarakat pada umumnya - sangat diperlukan,

Kedua, untuk menghindari berbagai upaya pihak perbankan syariah dalam tindakan penghindaran pajak yang justru menyebabkan tereduksinya karakteristik dasar perbankan syariah yang mengedepankan kejujuran, transparansi, nilai-nilai moralitas lainnya maka untuk sementara Direktorat jenderal pajak hendaknya segera mengeluarkan kebijakan yang membebaskan produk pembiayaan Perbankan syariah pada umumya dan pembiayaan murabahah khususnya dari pengenaan PPN. Hal ini sebenarnya bukan merupakan persoalan yang sulit, karena Direktorat jenderal pajak pada tahun 1995 pernah mengeluarkan surat edaran Nomor SE-63/PJ.53/1995 tanggal 29 Desember 1995 (SERI PPN 29-95) yang menegaskan bahwa penyerahan jasa penagihan rekening listrik dan telepon tidak terutang PPN, padahal berdasarkan memori penjelasan Pasal 13 Peraturan Pemerintah Nomor 50 Tahun 1994 telah menegaskan bahwa apabila jasa yang dilakukan oleh perusahaan perbankan tidak dapat dilakukan oleh perusahaan lain yang bukan bank, maka atas jasa ini tidak terutang PPN. tetapi kalau jasa yang dilaku-kan oleh perusahaan bank itu dapat dilakukan oleh perusahaan: selain bank, maka atas penyerahan jasa ini dikenakan PPN. Dalam hal ini jasa penagihan rekening listrik dan telepon termasuk jasa yang seharusnya dikenakan PPN karena bisa dilakukan oleh perusahaan lain yang bukan bank. ${ }^{20}$

${ }^{20}$ Untung Sukardji, Pajak Pertambahan Nilai, (Jakarta: Rajawali Press, 2003), Cet. 6, hlm. 87-88
Ketiga, bagi pihak-pihak terkait dengan perbankan syariah yang telah melakukan tindakan penghindaran pajak dengan melakukan berbagai macam cara yang memang masih kategori penghindaran pajak secara yuridis agar menghentikan cara-cara tersebut. Karena tindakan seperti itu justru akan mencenderai atau mencoreng wajah perbankan yang didasarkan atas nilai-nilai syariat Islam yang luhur yang dalam ajaranya sangat menekankan aspek subtansi akad (maudhu/maqsad al-aqd) dari pada hanya sekedar formalitas (mabani)nya. Sebagai gantinya upaya dialog antara para pihak yang terkait dengan perbankan syariah dan pihak Direktorat jenderal pajak Departemen Keuangan perlu lebih diintensifkan untuk mencapai kemaslahatan bersama.

\section{F. Kesimpulan}

Dari paparan di atas dapat diperoleh kesimpulan sebagai berikut:

a. Hal-hal yang melatarbelakangi terjadinya persoalan hukum mengenai pengenaan PPN di perbankan syariah adalah disebabkan perundang-undangan yang mengatur tentang PPN di perbankan tidak menjelaskan secara eksplisit, tegas dan jelas bahwa produk pembiayaan murabahah di perbankan syariah yang berbasiskan akad jual beli termasuk jasa perbankan yang dikecualikan dari PPN sebagaimana jasa yang ada pada perbankan konvensional. Akibatnya timbul penafsiran yang berbeda antara Direktorat Jenderal Pajak dan Pihak Bank Indonesia.

Dialog No. 67 Tahun XXXII, Juli 2009 
b. Persoalan yuridis yang muncul dalam persoalan ini adalah, a). persoalan lembaga yang punya otoritas menafsirkan keumuman dan ketidakjelasan perundangundangan tentang PPN di Perbankan. Dalam hal ini Bank Indonesia idealnya yang punya otoritas untuk menjelaskan apakah murabahah termasuk jasa perbankan atau tidak. Hal ini sesuai dengan Pasal 4A ayat (3) jo. Pasal 5 huruf d dan Pasal 8 huruf a Peraturan Pemerintah Nomor 144 Tahun 2000. b). persoalan pertentangan antara surat Direktorat Jenderal Pajak no. S-103/PJ.3/199 dengan Surat nomor No. 243/PJ.53/ 2003 dan S-1071/PJ.53/2003 jo S-65/ PJ.53/2006. Dalam hal ini karena PBI No.6/17/2004 jo PBI Nomor 9/ 19/PBI/2007 telah menegaskan bahwa dalam pembiayaan murabahah bank syariah hanya berfungsi sebagai penyedia dana/ fungsi intermediary maka PBI inilah yang merupakan peraturan perundang-undangan yang kuat untuk dijadikan dasar hukum dibandingan surat Direktorat Jenderal Pajak tersebut, apalagi surat Dirjen pajak tidak masuk dalam kategori Perundangundangan menurut UndangUndang No. 10 tahun 2004 tentang Pembentukan Peraturan Perundang-Undangan. c).persoalan pengelakan/penghindaran pajak yang dilakukan perbankan syariah dengan mengubah model akad murabahah, meskipun cara ini masuk kategori penghindaran pajak yuridis tetapi dari prinsip hukum islam jelas menyalahi tujuan akad (maudhu al-Aqd). d). persoalan istilah pajak ganda (double tax) sebenarnya tidak tepat digunakan dalam persoalan PPN pada pembiayaan murabahah.[] 